\title{
Tips for Integrating Land and Wildlife Management: Deer in Ranchlands $\mathbf{s}^{1}$
}

\author{
William M. Giuliano, John M. Olson, and Cailey Thomas²
}

Prized by hunters and wildlife enthusiasts alike, whitetailed deer are a popular species found throughout Florida. As such, they are often the focus of management for landowners, managers, and lessees who want to improve deer populations while maintaining other land uses such as agriculture.

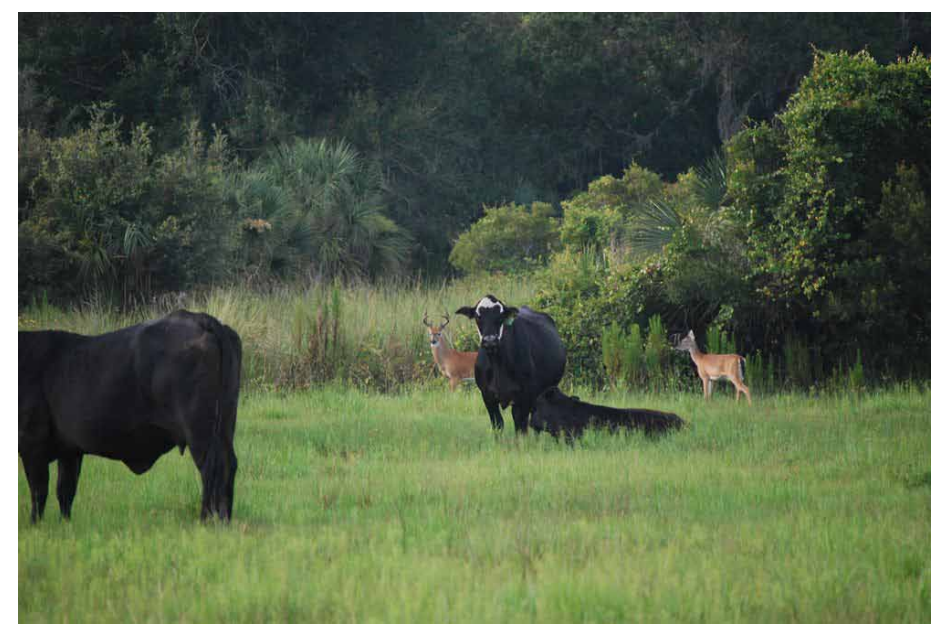

Figure 1. What often limits deer populations in Florida's ranchlands is the availability of nutritious foods.

Credit: Robert Hoffman

In Florida, most native habitat for deer is naturally poor, leading to relatively low deer densities and productivity, and lower-quality deer with smaller bodies and antlers. Some of these effects are the result of poor soil conditions leading to abundant but lower-quality deer foods. Heavily leached and acidic soils that spend extended periods either dry or saturated retain few available nutrients for plants, resulting in deer forage that can't deliver the nutrients that permit deer to grow larger bodies and antlers or high population densities. Similarly, "improved" ranchlands, which are often monotypic, provide poor deer forage.

To be healthy and successful, deer need good-quality food, water, and cover, and these must be distributed throughout their ranges. Water is typically good and abundant on Florida ranchlands and does not usually limit deer. And, with the exception of large expanses of improved pasture and range and intensively cropped areas, lack of cover typically won't inhibit deer either. However, what do frequently limit deer across the state are the poor abundance and distribution of good food. No single plant species can provide all that a deer needs to meet its nutritional requirements. In addition to having generally low-quality foods, ranchlands often have a low diversity of food sources, further reducing the quality of habitat for deer. Ranchland management for deer should therefore focus on providing a diversity of abundant, high-quality foods. Deer are browsers, which means that they eat mostly parts of woody plants. In order of importance, their favorite foods include the following: hard mast (such as acorns) over soft mast (such as persimmon fruit) over forbs (such as clover) over other browse (such as green briar leaves and twigs). Their least favorite foods are grasses (such as bluestem).

1. This document is WEC330, one of a series of the Department of Wildlife Ecology and Conservation, Florida Cooperative Extension Service, Institute of Food and Agricultural Sciences, University of Florida. Original publication date January 2013. Visit the EDIS website at http://edis.ifas.ufl.edu.

2. William M. Giuliano, professor; John M. Olson, graduate assistant; and Cailey Thomas, graduate assistant; Department of Wildlife Ecology and Conservation, University of Florida, Gainesville, FL 32611. 
Florida ranchlands contain a mix of habitats and land uses. It is important to manage the composition of each habitat type as well as the location of each in relation to the others on the ranch to increase diversity and enhance the ranch for deer. Below are some deer habitat improvement tips that focus primarily on raising the quality of deer forage but that also will help you grow better cover by improving plant diversity and productivity.

\section{Tips}

- Promote native over improved pastures, hayfields, and range. If improved areas are needed, use a diversity of plant species rather than a monoculture, and intersperse improved and native areas within fields, pastures, or management units.

- Create an "old field" or "rough" environment that includes forbs and shrubs.

- Lower livestock stocking rates; consider stocking at a rate half that recommended by the USDA for the system.

- Rotate livestock rather than using a continuous grazing system; consider exclosures to keep livestock from certain areas.

- Create and maintain fencerows (i.e., vegetated fences) to provide abundant grasses, forbs, shrubs, and trees.

- Generate disturbance by disking, roller chopping, and burning.

- Manage soft edges or ecotones (i.e., transition zones) where fields meet other habitats, such as forests, that include a diversity of plants and structures.

- Reduce herbicide use.

- Reduce field size to increase edge.

- Manage food plots of 1 - 3 acres each containing a mix of grasses and forbs during both cool and warm seasons on more than $3 \%$ of the land.

- Provide supplemental feed; commercial feeds or chows should be used because single grains such as corn have little nutritional value (through feeders or by spreading on the ground; 1 feeder/30 deer or 150 acres).

- Maintain odd areas such as ditches, roadsides, corners of fields, etc., that include a diversity of plant species and structures.
These recommendations should be considered in the context of the overall ranch. For example, when locating a food plot, consider putting it near a pine plantation, which has little food value for deer, rather than a fallow field or mature oak stand. An extensive discussion and descriptions of the tips provided here can be found in Understanding White-tailed Deer: Florida and the Southeast by W.M. Giuliano, Elina Garrison, and B.J. Schad available through the UF/IFAS Extension Bookstore (http://ifasbooks.ifas.ufl. edu).

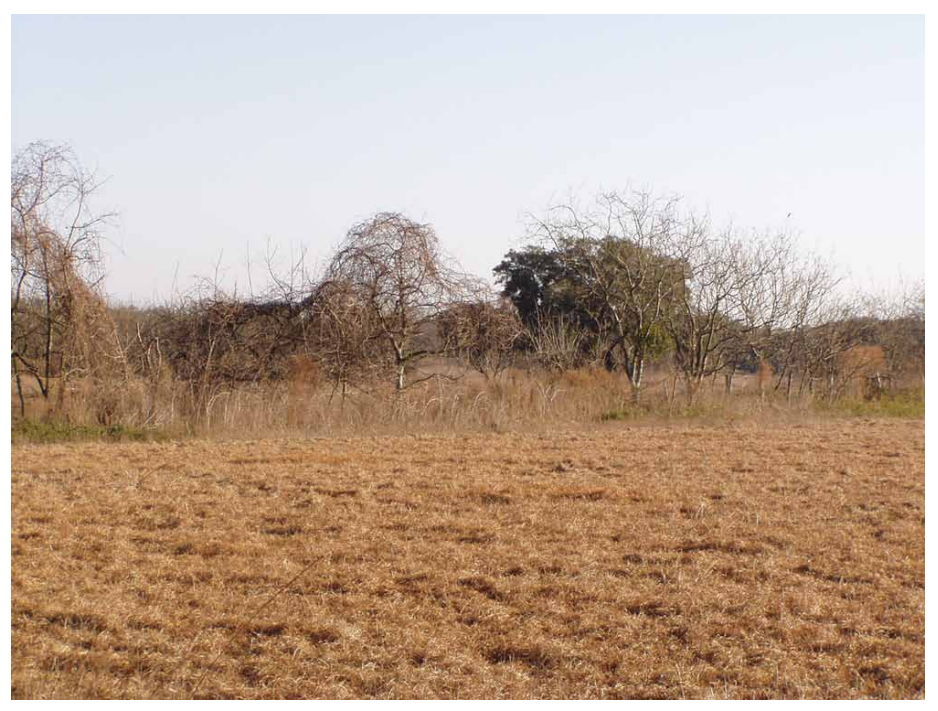

Figure 2. Create and maintain fencerows and promote native over improved range to enhance deer habitat.

Credit: William Giuliano 